\title{
Palladium(II) on $4 \AA$ A Molecular Sieves: A Simple and Reusable Catalyst for the Preparation of Ynones
}

\author{
Kinga Juhász ${ }^{1} \cdot$ Zoltán Hell $^{1}$
}

Received: 16 March 2020 / Accepted: 22 April 2020 / Published online: 9 May 2020

(c) The Author(s) 2020

\section{Abstract}

$\mathrm{Pd}^{2+}$ on $4 \AA$ molecular sieves support has been prepared and investigated. The catalyst has successfully been used in the reaction of acyl chlorides and terminal alkynes yielding ynones. The catalyst can be reused without significant loss of activity.

\section{Graphic Abstract}<smiles>[R]c1ccc(C(=O)OC)cc1</smiles>

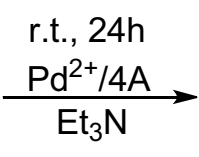<smiles>[R]C#CC(=O)c1ccc([R])cc1</smiles>

$$
\begin{gathered}
\mathrm{R}=\text { alkyl, alkoxy, } \mathrm{Cl}, \mathrm{Br}, \mathrm{I}, \mathrm{NO}_{2} \\
\mathrm{R}^{\prime}=\mathrm{Ph}, \mathrm{C}_{5} \mathrm{H}_{11}, 2 \text {-hydroxy-but-2-yl } \\
10 \text { examples }
\end{gathered}
$$$$
25-92 \% \text { yield }
$$

Keywords Palladium $\cdot 4 \AA$ molecular sieves $\cdot$ Ynones $\cdot$ Heterogeneous catalysis

\section{Introduction}

Ynones are the analogues of benzalacetophenone and form an important group of organic chemical substances, since they are key synthetic intermediates of a variety of biologically active heterogeneous compounds [1-11]. Ynones are widely used as anti-inflammatory and anticarcinogenic [12] agents. They are also important intermediates in the synthesis of dyes for luminescent solar concentrators [13-15].

Due to their importance several synthetic routes were developed for their synthesis, such as the oxidation of alkynes [16-18], propargylic alcohols [19], the reaction of terminal alkynes with nitriles [20], cross-coupling reactions of terminal alkynes with organic halides in the presence of

Zoltán Hell

zhell@mail.bme.hu

1 Department of Organic Chemistry and Technology, Budapest University of Technology and Economics, Budapest 1111, Hungary carbon monoxide gas [21-23]. However the most important process is the reaction between terminal alkynes and carboxylic acid derivatives called the acyl Sonogashira reaction. The acyl Sonogashira reaction is usually performed in the presence of a palladium catalyst, a ligand (mostly phosphorous compounds) and $\mathrm{CuI}$ [24-26].

Several catalytic methods were developed for this reaction using palladium, copper or bimetallic catalysts. Ynones were synthesized in the presence of copper or palladium nanoparticles [27-34] and different supported metal complexes $[35,36]$. The use of tin silicates was also reported [37]. As a copper- and palladium-free method a polystyrene-supported zinc bromide-ethylene diamine complex was described for the reaction [38].

These methods have their advantages and disadvantages, but an efficient heterogeneous catalytic method may be a good alternative.

Our group has been working on the preparation of different supported metal catalysts and the elaboration of 
various heterogeneous catalytic reactions. Methods have been developed for the palladium-catalysed cross-coupling reactions, e.g. $\mathrm{Pd}^{0}$ on $\mathrm{Mg}$-La mixed oxide in the Heck[39], Sonogashira- [40] and Suzuki-coupling [41], or palladium-copper bimetallic catalysts in the Suzuki-coupling $[42,43]$. In continuation of our interest, in this paper we present our results obtained with $\mathrm{Pd}^{2+}$ on $4 \AA$ molecular sieves support in the cross-coupling reaction of different acyl chlorides and terminal alkynes.

\section{Experimental}

Morphology of the catalyst samples was investigated by a JEOL 6380LVa (JEOL, Tokyo, Japan) type scanning electron microscope and elemental mapping was also accomplished using the energy-dispersive X-ray detector of the equipment. Each specimen was fixed by conductive double-sided carbon adhesive tape and sputtered by gold (using a JEOL 1200 instrument). Applied accelerating voltage and working distance were between 15 and $30 \mathrm{kV}$ and 10 and $12 \mathrm{~mm}$, respectively.

The nitrogen adsorption/desorption isotherms were measured at $-196{ }^{\circ} \mathrm{C}$ with a computer-controlled Nova 200e (Quantachrome) instrument. The apparent surface area (SBET) was calculated using the Brunauer-Emmett-Teller (BET) model. Prior to the adsorption measurement, the samples were evacuated at $110{ }^{\circ} \mathrm{C}$ for $24 \mathrm{~h} .{ }^{1} \mathrm{H}$ and ${ }^{13} \mathrm{C}$ NMR spectra were made on BRUKER Avance-300 instrument using TMS as an internal standard in $\mathrm{CDCl}_{3}$.

GC-MS measurements were performed on an Agilent 6850-GC-5975C-MS chromatograph using a $15 \mathrm{~m} \times 0.25 \mathrm{~mm}$ column with a $0.25 \mathrm{~mm}$ HP-5MS layer. The initial temperature of the column was $100{ }^{\circ} \mathrm{C}$ and it was heated up to $325{ }^{\circ} \mathrm{C}$ with a $5 \mathrm{~min}$ run time. The carrier gas was $\mathrm{He}$ and the operation mode was split.

All compounds and solvents were purchased from Merck Hungary Ltd.

\subsection{Preparation of the Catalysts}

\subsubsection{Preparation of the $\mathrm{Pd}^{2+} / 4 \mathrm{~A}$ Catalyst}

Four Angstrom molecular sieves (4A) were impregnated with $\mathrm{PdCl}_{2}$ as follows: $1 \mathrm{mmol}(0.18 \mathrm{~g})$ of $\mathrm{PdCl}_{2}$ was dissolved in $100 \mathrm{ml}$ of deionised water and stirred with $1 \mathrm{~g} \mathrm{4A}$ at room temperature for $24 \mathrm{~h}$. The solid was filtered, washed with deionised water and with acetone, then dried in an oven at $150{ }^{\circ} \mathrm{C}$ for $1 \mathrm{~h}$. Samples were heated at $120^{\circ} \mathrm{C}$ for $1 \mathrm{~h}$ before the reaction.

\subsubsection{Preparation of the $\mathrm{Cu}^{2+} / 4 \mathrm{~A}$ Catalyst}

The $\mathrm{Cu}^{2+} / 4 \mathrm{~A}$ catalyst was prepared according to 2.1.1, where instead of $\mathrm{PdCl}_{2} \mathrm{CuCl}_{2}(0.17 \mathrm{~g})$ was used.

\subsubsection{Preparation of the $\mathrm{Pd}^{2+} / \mathrm{Cu}^{2+} / 4 \mathrm{~A}$ Catalyst}

The bimetallic catalyst was prepared with the co-impregnation method as described earlier [42]. $\mathrm{CuCl}_{2}$ and $\mathrm{PdCl}_{2}(5: 1$ molar ratio) were added simultaneously to the suspension of $4 \mathrm{~A}$ in deionised water. After the filtration the thermal treatments were the same as described in 2.1.1.

\subsection{Typical Reaction Conditions}

\subsubsection{General Procedure for the Preparation of Ynones}

Acyl chloride $(1.1 \mathrm{mmol})$, a terminal alkyne $(1 \mathrm{mmol})$, triethylamine $(1.05 \mathrm{mmol})$ and the catalyst $(0.1 \mathrm{~g})$ were stirred in a test tube at room temperature for $24 \mathrm{~h}$. After completion, the reaction mixture was diluted with acetone, the solid was filtered and washed with acetone, then the filtrate was evaporated. The residue was diluted with diethyl ether, extracted with a saturated $\mathrm{K}_{2} \mathrm{CO}_{3}$ solution. The organic phase was dried over $\mathrm{Na}_{2} \mathrm{SO}_{4}$ and the solvent was evaporated. The crude product was purified via column chromatography using hexane:ethyl acetate 10:1 as the eluent. The products were subjected to ${ }^{1} \mathrm{H}$ and ${ }^{13} \mathrm{C}$ NMR spectroscopy.

\subsubsection{Characterization of the Products}

1,3-Diphenyl-2-propyn-1-one (3a) [44, 45] Yellow oil. ${ }^{1} \mathrm{H}$ NMR $\left(500 \mathrm{MHz}, \mathrm{CDCl}_{3}\right) \delta(\mathrm{ppm}): 7.39-7.42(\mathrm{t}, 2 \mathrm{H})$; 7.46-7.47 (d, 1H); 7.49-7.52 (t, 2H); 7.60-7.63 (t, 1H); 7.67-7.68 (d, 2H); 8.21-8.23 (d, 2H). ${ }^{13} \mathrm{C}$ NMR $(125 \mathrm{MHz}$, $\left.\mathrm{CDCl}_{3}\right) \delta(\mathrm{ppm}): 86.9 ; 93.1 ; 120.1 ; 128.6 ; 128.7 ; 129.6$; $130.8 ; 133.1 ; 134.1 ; 136.9 ; 178$.

1-(4-Methylphenyl)-3-phenyl-2-propyn-1-one (3b) [46] Yellow solid. ${ }^{1} \mathrm{H}$ NMR $\left(500 \mathrm{MHz}, \mathrm{CDCl}_{3}\right) \delta$ (ppm): 2.44 (s, 3H); 7.30-7.31 (d, 2H); 7.40-7.43 (t, 2H); 7.46-7.49 (m, 1H); 7.67-7.69 (d, 2H); 8.11-8.12 (d, 2H). ${ }^{13} \mathrm{C}$ NMR $\left(125 \mathrm{MHz}, \mathrm{CDCl}_{3}\right) \delta$ (ppm): 21.8; 87.0; 92.6; 120.3; 128.7; $129.4 ; 129.7 ; 130.7 ; 133.0 ; 134.7 ; 145.2 ; 177.7$.

1-(4-tert-Butylphenyl)-3-phenyl-2-propyn-1-one (3c) [47] Yellow oil. ${ }^{1} \mathrm{H}$ NMR (500 MHz, $\left.\mathrm{CDCl}_{3}\right) \delta(\mathrm{ppm}): 1.38$ (s, 9H); 7.39-7.42 (t, 2H); 7.45-7.48 (m, 1H); 7.51-7.54 $(\mathrm{m}, 3 \mathrm{H}) ; 7.66-7.68(\mathrm{~d}, 2 \mathrm{H}) ; 8.15-8.17(\mathrm{~d}, 2 \mathrm{H}) .{ }^{13} \mathrm{C} \mathrm{NMR}$ $\left(125 \mathrm{MHz}, \mathrm{CDCl}_{3}\right.$ ) $\delta$ (ppm): 31.1; 35.3; 87.1; 92.6; 120.3; $125.6 ; 128.7 ; 129.6 ; 130.5 ; 133.0 ; 134.6 ; 158.1 ; 177.7$.

1-(2-Ethoxyphenyl)-3-phenyl-2-propyn-1-one (3d) [48] Yellow oil. ${ }^{1} \mathrm{H}$ NMR (500 MHz, $\mathrm{CDCl}_{3}$ ) $\delta$ (ppm): 1.42-1.47 (t, 3H); 4.13-4.19 (q, 2H); 6.96-7.03 (m, 2H); 7.34-7.43 (m, 3H); 7.46-7.52 (m, 1H); 7.58-7.61 (d, 2H); 7.98-8.01 
(dd, $1 \mathrm{H}) .{ }^{13} \mathrm{C} \mathrm{NMR}\left(125 \mathrm{MHz}, \mathrm{CDCl}_{3}\right) \delta(\mathrm{ppm}): 14.7 ; 64.5$; $89.6 ; 91.5 ; 113.1 ; 120.2 ; 120.8 ; 127.1 ; 128.6 ; 130.3 ; 131.9$; $132.7 ; 134.9 ; 159.2 ; 176.9$.

1-(3-Chlorophenyl)-3-phenyl-2-propyn-1-one (3e) [49] Yellow solid. ${ }^{1} \mathrm{H}$ NMR (500 MHz, $\left.\mathrm{CDCl}_{3}\right) \delta(\mathrm{ppm})$ : 7.44-7.47 (m, 3H); 7.49-7.52 (m, 1H); 7.59-7.61 (m, 1H); 7.69-7.70 (m, 2H); 8.10-8.12 (m, 1H); 8.17-8.18 (m, 1H). ${ }^{13} \mathrm{C}$ NMR $\left(125 \mathrm{MHz}, \mathrm{CDCl}_{3}\right) \delta(\mathrm{ppm}): 86.5 ; 93.9 ; 119.8$; $127.7 ; 128.8 ; 129.4 ; 129.9 ; 131.1 ; 133.2 ; 134.0 ; 135.0$; $138.4 ; 176.5$.

1-(4-Bromophenyl)-3-phenyl-2-propyn-1-one (3f) [50] Yellow oil. ${ }^{1} \mathrm{H}$ NMR $\left(500 \mathrm{MHz}, \mathrm{CDCl}_{3}\right) \delta(\mathrm{ppm}): 7.40-7.45$ (m, 5H); 7.63-7.66 (dd, 2H); 7.69-7.71 (dd, 1H); 8.06-8.08 $(\mathrm{dd}, 1 \mathrm{H}) .{ }^{13} \mathrm{C} \mathrm{NMR}\left(125 \mathrm{MHz}, \mathrm{CDCl}_{3}\right) \delta(\mathrm{ppm}): 87.9 ; 94.2$; $120.0 ; 121.2 ; 127.4 ; 128.7 ; 130.9 ; 131.9 ; 133.1 ; 133.5$; $134.9 ; 137.3 ; 177.5$.

1-(4-Nitrophenyl)-3-phenyl-2-propyn-1-one (3 h) Brown solid. ${ }^{1} \mathrm{H}$ NMR $\left(500 \mathrm{MHz}, \mathrm{CDCl}_{3}\right) \delta(\mathrm{ppm}): 7.45-7.48(\mathrm{t}$, 2H); 7.53-7.56 (t, 1H); 7.71-7.73 (d, 2H); 8.23-8.29 (m, $1 \mathrm{H}) ; 8.38(\mathrm{~s}, 3 \mathrm{H}) .{ }^{13} \mathrm{C}$ NMR $\left(125 \mathrm{MHz}, \mathrm{CDCl}_{3}\right) \delta(\mathrm{ppm})$ : 86.6; 95.4; 119.4; 123.4; 123.9; 128.9; 130.5; 130.9; 131.5; $133.3 ; 175.9$.

1-Phenyl-2-octyn-1-one (3i) [46] Brown solid. ${ }^{1} \mathrm{H}$ NMR $\left(500 \mathrm{MHz}, \mathrm{CDCl}_{3}\right) \delta(\mathrm{ppm}): 0.91-0.95(\mathrm{t}, 3 \mathrm{H}) ; 1.31-1.51$ $(\mathrm{m}, 4 \mathrm{H}) ; 1.64-1.73(\mathrm{~m}, 2 \mathrm{H}) ; 2.47-2.52(\mathrm{t}, 2 \mathrm{H}) ; 7.45-7.60$ $(\mathrm{m}, 2 \mathrm{H}) ; 7.65-7.70(\mathrm{~m}, 1 \mathrm{H}) ; 8.13-8.17(\mathrm{t}, 2 \mathrm{H}) .{ }^{13} \mathrm{C} \mathrm{NMR}$ $\left(125 \mathrm{MHz}, \mathrm{CDCl}_{3}\right) \delta$ (ppm): 13.9; 19.2; 22.1; 27.5; 31.1; $79.7 ; 96.9 ; 128.5 ; 129.6 ; 133.8 ; 136.9 ; 178.3$.

4-Hydroxy-4-methyl-1-phenyl-2-hexyn-1-one (3j) Brown solid. ${ }^{1} \mathrm{H}$ NMR (500 MHz, $\left.\mathrm{CDCl}_{3}\right) \delta(\mathrm{ppm}): 1.1-1.15(\mathrm{t}$, $3 \mathrm{H}) ; 1.63(\mathrm{~s}, 1 \mathrm{H}) ; 1.80-1.96(\mathrm{~m}, 2 \mathrm{H}) ; 7.44-7.49(\mathrm{~m}, 2 \mathrm{H})$; $7.58-7.63(\mathrm{~m}, 1 \mathrm{H}) ; 8.11-8.13(\mathrm{~d}, 2 \mathrm{H}) .{ }^{13} \mathrm{C} \mathrm{NMR}(125 \mathrm{MHz}$, $\left.\mathrm{CDCl}_{3}\right) \delta(\mathrm{ppm}): 8.9 ; 28.6 ; 36.1 ; 68.9 ; 81.1 ; 97.5 ; 120.9$; $126.3 ; 127.2 ; 128.5 ; 128.6 ; 129.6 ; 130.2 ; 133.7 ; 134.2$; 177.9.

\section{Results and Discussion}

During our research on the elaboration of new heterogeneous catalytic methods several different supports were used (e.g. $\mathrm{Mg}-\mathrm{La}$ mixed oxide, different types of $\mathrm{Mg}-\mathrm{Al}$ hydrotalcites and 4A molecular sieves). Among them, the 4A molecular sieves has several excellent properties. It is easily accessible from commercial sources and it is not sensitive to the atmospheric carbon dioxide in contrary to the mixed oxides or the different hydrotalcites. The different supported metal catalysts can easily be prepared from $4 \mathrm{~A}$ and the corresponding metal salt in deionised water (see Experimental). During our research we have successfully applied 4A-supported metal catalysts in different organic syntheses, e.g. $\mathrm{Cu}^{2+} / 4 \mathrm{~A}$ in the $\mathrm{A}_{3}$-coupling yielding propargylamines [51], as well as in the selective 1,4-additon of Grignard compounds to chalcones
[52]. $\mathrm{La}^{3+} / 4 \mathrm{~A}[53,54]$ or $\mathrm{Ti}^{4+} / 4 \mathrm{~A}$ [55] were successfully used in multicomponent reactions yielding heterocycles. In this acyl Sonogashira reaction $\mathrm{Pd}^{2+} / 4 \mathrm{~A}$ gave good results, thus this was used in the further experiments, no other support has been tested.

A homogeneous catalytic Sonogashira reaction is generally carried out with $\operatorname{Pd}(0)$ catalysts in the presence of different ligands. In heterogeneous catalytic methods Pd(II) compounds may also have good catalytic activity, as shown in our preliminary experiments. A similar effect has already been observed during the arylation of pyrrole with aryl halides in the presence of $4 \mathrm{~A}$-supported copper catalysts [56]. $\mathrm{A} \mathrm{Pd}^{0} / 4 \mathrm{~A}$ catalyst is more sensitive, requires an inert atmosphere and it has pyrophoric properties, thus $\mathrm{Pd}^{2+} / 4 \mathrm{~A}$ can be used easier.

The structure of the $\mathrm{Pd}^{2+} / 4 \mathrm{~A}$ catalyst was investigated by scanning electron microscopy (SEM) (Fig. 1). The distribution of the palladium on the surface of the support was also examined. According to the EDS measurement the palladium content is $9.32 \mathrm{w} / \mathrm{w} \%$ and the palladium is evenly distributed on the surface of the support (Fig. 2). The palladium content of the catalyst measured by ICP-OES was $10 \%$, which is in accordance with the theoretical value (9.6\%). Comparing the results of the EDS and the ICP-OES measurements, palladium is located on the surface of the catalyst.

The results of the BET measurement showed a significant decrease of the surface from 800 (pure support) to 59 $\mathrm{m}^{2} / \mathrm{g}$. This also verifies the presence of the palladium on the surface.

In the literature the preparation of ynones by the reaction of acyl chlorides and terminal alkynes was described mostly with copper, palladium or bimetallic catalysts. So first, we examined our molecular sieve supported $\mathrm{Pd}, \mathrm{Cu}$ and $\mathrm{Pd} / \mathrm{Cu}$ catalysts in a model reaction of benzoyl chloride and phenylacetylene, in 1,4-dioxane, in the presence of triethylamine

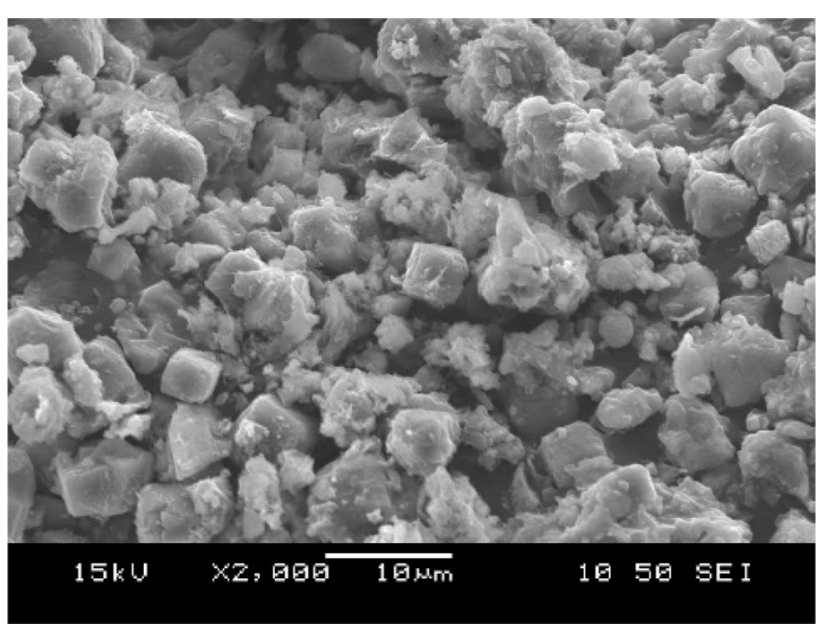

Fig. 1 SEM image of the $\mathrm{Pd}^{2+} / 4 \mathrm{~A}$ catalyst 


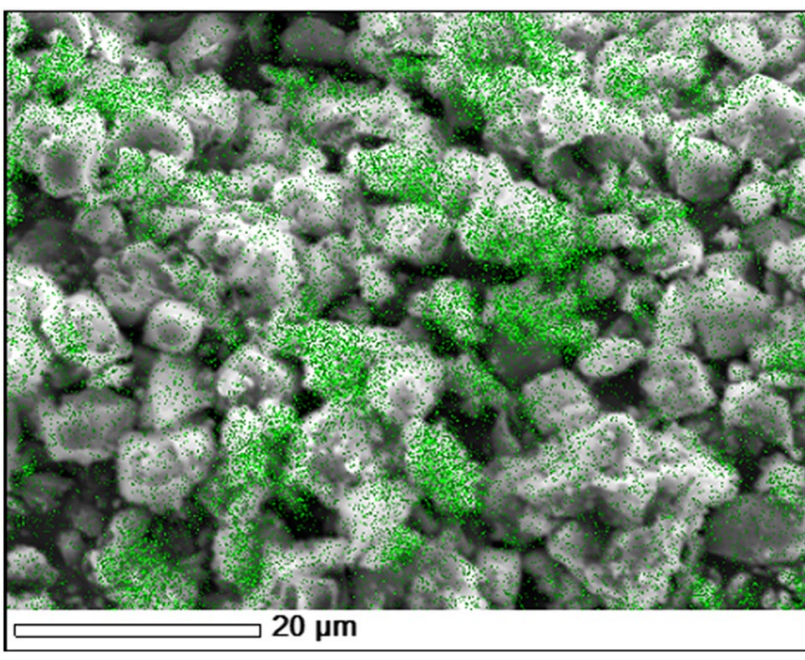

Fig. 2 Palladium on the surface of the support (SEM EDS image of the $\mathrm{Pd}^{2+} / 4 \mathrm{~A}$ catalyst)

(Table 1, entries 1-3). In our previous experiments (e.g. $[43,53]$.) generally $0.1 \mathrm{~g}$ catalyst/ $1 \mathrm{mmol}$ substrate was the most efficient ratio in the case of the 4A-supported catalysts, thus we used the same amount in these experiments. This amount is higher than which are used in the homogeneous methods, but the heterogeneous catalyst can be fully recovered from the reaction mixture and it can be reused several times. We found that only the $\mathrm{Pd}^{2+} / 4 \mathrm{~A}$ catalyst was efficient in the acyl Sonogashira reaction. With the bimetallic $\mathrm{Pd}^{2+} /$ $\mathrm{Cu}^{2+} / 4 \mathrm{~A}$ catalyst no product was formed. This catalyst has been widely investigated earlier $[42,43]$. It was found, that during the impregnation a $\mathrm{Pd} / \mathrm{Cu}$ 1:1 alloy was formed which was responsible for the catalytic activity of this catalyst. The inactivity of this bimetallic catalyst in this reaction might be explained by the lower activity of this alloy. The reaction in the presence of the $\mathrm{Cu}^{2+} / 4 \mathrm{~A}$ catalyst also gave a very low yield. The weak results obtained with these two catalysts may indicate that copper on 4A support is not active enough in this reaction. Based on these results all further experiments were carried out with $\mathrm{Pd}^{2+} / 4 \mathrm{~A}$.

Next we examined the effect of the base on the yield of the reaction. According to the literature and the earlier experiences we tried $\mathrm{K}_{2} \mathrm{CO}_{3}$ and triethylamine. The advantage of the $\mathrm{K}_{2} \mathrm{CO}_{3}$ would be that it can be easily separated from the reaction mixture by filtration. However, triethylamine was found to be more effective in this reaction (Table 1, entries 3 and 4). In this case, the catalyst needs to be washed with ethanol before it can be reused, to remove the triethylamine hydrochloride salt.

After the suitable base was found, the reaction was carried out in different solvents. The best result could be achieved if no solvent was used (Table 1, entry 7).

Under the optimized reaction conditions a wide range of acyl chlorides and a few terminal alkynes were tested in the reaction (Table 2). The desired products were obtained in $25-92 \%$ yields. Benzoyl chloride and derivatives bearing electron-donating or electron-withdrawing groups were tested in the reaction. In case of the alkyl- and nitro-substituents the desired products were isolated in good to excellent yields (Table 2, entries 2, 3 and 8). Using acyl chlorides with halide substituents the yields were significantly lower and in case of the 2-iodobenzoyl chloride no product was formed (Table 2, entries 5-7). In this case the reaction mixture contained mainly 2 -iodobenzoic acid. The reason for these low yields can be the reactivity of the halide substituents on the acyl chlorides. The amount of the desired product decreases with the increasing reactivity of the halide substituents. Another influencing factor could be the position

Table 1 Optimization of the reaction conditions in the model reaction of benzoyl chloride and phenylacetylene

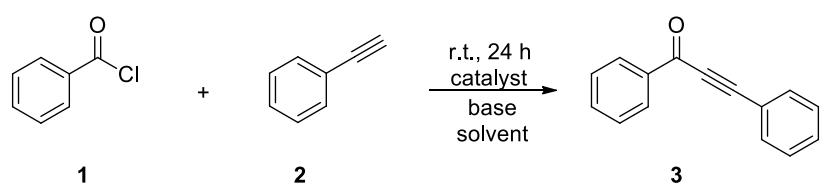

\begin{tabular}{lllll}
\hline Entry & Catalyst & $\mathrm{Base}$ & Solvent & Yield (\%) \\
\hline 1 & $\mathrm{Pd}^{2+/} \mathrm{Cu}^{2+} / 4 \mathrm{~A}$ & $\mathrm{Et}_{3} \mathrm{~N}$ & 1,4-dioxane & 0 \\
2 & $\mathrm{Cu}^{2+} / 4 \mathrm{~A}$ & $\mathrm{Et}_{3} \mathrm{~N}$ & 1,4-dioxane \\
3 & $\mathrm{Pd}^{2+} / 4 \mathrm{~A}$ & $\mathrm{Et}_{3} \mathrm{~N}$ & 1 ,4-dioxane & 70 \\
4 & $\mathrm{Pd}^{2+} / 4 \mathrm{~A}$ & $\mathrm{~K}_{2} \mathrm{CO}_{3}$ & 1,4 -dioxane & 50 \\
5 & $\mathrm{Pd}^{2+} / 4 \mathrm{~A}$ & $\mathrm{Et}_{3} \mathrm{~N}$ & toluene & 43 \\
6 & $\mathrm{Pd}^{2+} / 4 \mathrm{~A}$ & $\mathrm{Et}_{3} \mathrm{~N}$ & acetonitrile & 32 \\
7 & $\mathrm{Pd}^{2+} / 4 \mathrm{~A}$ & $\mathrm{Et}_{3} \mathrm{~N}$ & neat & 83 \\
\hline
\end{tabular}

Reaction conditions: $1.1 \mathrm{mmol}$ benzoyl chloride, $1 \mathrm{mmol}$ phenylacetylene, $1.05 \mathrm{mmol}$ base, $0.1 \mathrm{~g}$ catalyst ( $10 \mathrm{~mol} \% \mathrm{metal}), 3 \mathrm{~mL}$ solvent, r.t., $24 \mathrm{~h}$ 
Table 2 The reaction of acyl chlorides and terminal alkynes in the presence of triethylamine and $\mathrm{Pd}^{2+} / 4 \mathrm{~A}$ catalyst

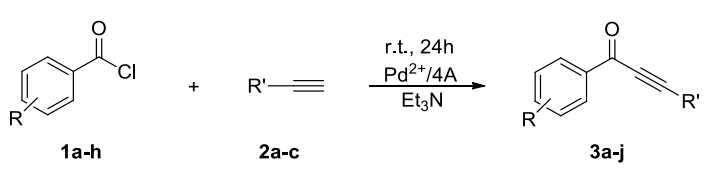

\begin{tabular}{llll}
\hline Entry & $\mathrm{R}$ & $\mathrm{R}$ & ${\text { Yield }(\%)^{\mathrm{a}}}^{\mathrm{a}}$ \\
\hline 1 & $\mathrm{H}$ & $\mathrm{Ph}$ & 83 \\
2 & $4-\mathrm{CH}_{3}$ & $\mathrm{Ph}$ & 64 \\
3 & $4-t e r t-\mathrm{C}_{4} \mathrm{H}_{9}$ & $\mathrm{Ph}$ & 73 \\
4 & $2-\mathrm{OC}_{2} \mathrm{H}_{5}$ & $\mathrm{Ph}$ & 38 \\
5 & $3-\mathrm{Cl}$ & $\mathrm{Ph}$ & 38 \\
6 & $4-\mathrm{Br}$ & $\mathrm{Ph}$ & 25 \\
$7^{\mathrm{c}}$ & $2-\mathrm{I}$ & $\mathrm{Ph}$ & 0 \\
$8^{\mathrm{c}}$ & $4-\mathrm{NO}_{2}$ & $\mathrm{Ph}$ & 92 \\
9 & $\mathrm{H}$ & $\mathrm{C}_{5} \mathrm{H}_{11}$ & $35^{\mathrm{b}}$ \\
10 & $\mathrm{H}$ & OH & $50^{\mathrm{b}}$ \\
& & \multicolumn{2}{c}{} \\
\hline
\end{tabular}

Reaction conditions: $1.1 \mathrm{mmol}$ acyl chloride, $1 \mathrm{mmol}$ terminal alkyne, $1.05 \mathrm{mmol}$ triethylamine, $0.1 \mathrm{~g}$ catalyst (10 mol\% Pd), r.t., $24 \mathrm{~h}$

${ }^{\mathrm{a}}$ Isolated yield

${ }^{\mathrm{b}}$ Determined by GC-MS, the product was not isolated

${ }^{\mathrm{c}}$ In $0.5 \mathrm{~mL}$ 1,4-dioxane<smiles>O=C(O)c1cccc(C(=O)c2ccccc2)c1</smiles>

Fig. 3 3-Benzoylbenzoic acid by-product

of the halide substituent. In case of the iodobenzoyl chloride the iodine atom is in ortho-position and therefore the reaction can be sterically hindered. In the reaction of 2-ethoxybenzoyl chloride the desired product was obtained only in $38 \%$ yield (Table 2, entry 4 ) proving also a steric hindrance of the ortho substituents. In case of 2-iodobenzoyl chloride and 4-nitrobenzoyl chloride 1,4-dioxane had to be added to the reaction mixture to assure the good miscibility.

Besides phenylacetylene, other terminal alkynes were investigated in the reaction. Using heptyne and 3-methyl1-pentin-3-ol the desired products were formed in only $35 \%$ and $50 \%$ yield, respectively (calculated from the GC-MS spectra, Table 2, entries 9 and 10). In these cases a by-product in equivalent amount to the product was found. Based on the GC-MS (m/z at 226) and ${ }^{13} \mathrm{C} \mathrm{NMR}$ spectra (peak at ca. $172 \mathrm{ppm}$ ) this by-product could be identified as 3-benzoyl-benzoic acid (Fig. 3), which can be formed in a Friedel-Crafts type reaction of benzoyl chloride. The two products could not be separated. Although our catalyst is basic in bulk phase, the acid sites on the
Reusability of the $\mathrm{Pd}^{2+} / 4 \mathrm{~A}$ catalyst

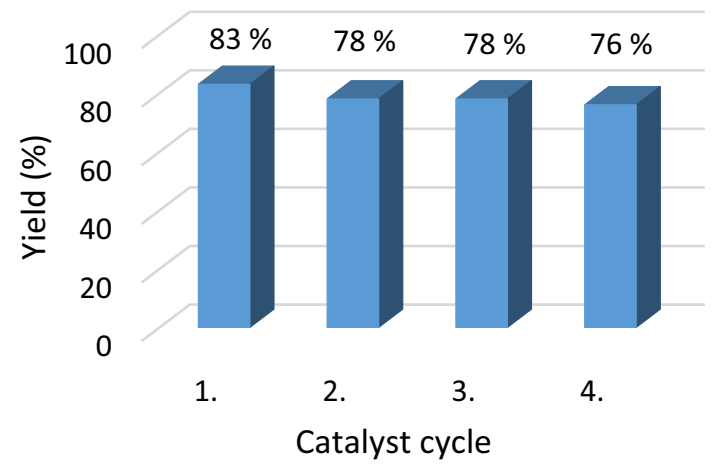

Fig. 4 The reusability of the $\mathrm{Pd}^{2+} / 4 \mathrm{~A}$ catalyst

surface formed by the incorporated metal may catalyse an $\mathrm{S}_{\mathrm{E}}$ Ar type reaction. This side reaction may become significant, if the reactivity of the alkyne is not high enough.

The reusability of the catalyst was tested as well. Therefore, the catalyst filtered from the reaction mixture was washed with ethanol and dried at $120{ }^{\circ} \mathrm{C}$ for $1 \mathrm{~h}$. Afterwards it was reused in another reaction. It was found, that the catalyst can be simply reused. The experiment was repeated 3 times and the results are shown in Fig. 4. The slight decrease in the yield after the first run can be explained with triethylamine hydrochloride residues 
precipitated to the surface of the catalyst, which can cover the active metals sites.

\section{Conclusion}

In conclusion, the $\mathrm{Pd}^{2+} / 4 \mathrm{~A}$ catalyst proved to be efficient in the reaction of acyl chlorides and terminal alkynes. The desired ynones were formed in all cases, except with 2-iodobenzoyl chloride. However, in some cases a large amount of a by-product was formed. A great advantage of the catalyst is the easy preparation and recovery.

Acknowledgements Open access funding provided by Budapest University of Technology and Economics (BME). The authors express their gratitude to Prof. K. László for the BET surface determination. The research reported in this paper has been supported by the National Research, Development and Innovation Fund (TUDFO/51757/2019ITM, Thematic Excellence Program).

\section{Compliance with Ethical Standards}

Conflict of interest The authors declare that they have no conflict of interest.

Open Access This article is licensed under a Creative Commons Attribution 4.0 International License, which permits use, sharing, adaptation, distribution and reproduction in any medium or format, as long as you give appropriate credit to the original author(s) and the source, provide a link to the Creative Commons licence, and indicate if changes were made. The images or other third party material in this article are included in the article's Creative Commons licence, unless indicated otherwise in a credit line to the material. If material is not included in the article's Creative Commons licence and your intended use is not permitted by statutory regulation or exceeds the permitted use, you will need to obtain permission directly from the copyright holder. To view a copy of this licence, visit http://creativecommons.org/licenses/by/4.0/.

\section{References}

1. Fawcett CH, Firu RD, Spencer DM (1971) Physiol Plant Pathol 1:163

2. Mead D, Asato AE, Denny M, Liu RSH, Hanzawa Y, Taguchi T, Yamada A, Kobayashi N, Hosoda A, Kobayashi Y (1987) Tetrahedron Lett 28:259

3. Chowdhury C, Kundu NG (1999) Tetrahedron 55:7011

4. Quesnelle CA, Gill P, Dodier M, Laurent DS, Serrano-Wu M, Marinier A, Martel A, Mazzucco CE, Stickle TM, Barrett JF, Vyas DM, Balasubramanian BN (2003) Bioorg Med Chem Lett 13:519

5. Reid W, Koenig E (1972) Justus Liebigs Ann Chem 24:755

6. Hojo M, Omita K, Hosomi A (1993) Tetrahedron Lett 34:485

7. Arcadi A, Marenelli F, Rossi E (1999) Tetrahedron 55:13233

8. Kelin AV, Sromek AW, Gevorgyan VJ (2001) Am Chem Soc 123:2074

9. Jeevnandan A, Narkunan K, Ling YJ (2001) Org Chem 66:6014

10. Grotjahn DB, Van S, Combs D, Lev DA, Schneider C, Rideout M, Meyer C, Hernandez G, Mejorado L (2002) J Org Chem 67:9200

11. Karpov AS, Muller T (2003) J Org Lett 5:3451
12. Maydt D, De Spirt S, Muschelknautz C, Stahl W, Müller TJJ (2013) Xenobiotoca 43(8):711-718

13. Albano G, Aronica LA, Biver T, Detti R, Pucci A (2018) ChemistrySelect 3:1749-1754

14. Albano G, Colli T, Nucci L, Charaf R, Biver T, Pucci A, Aronica LA (2019) Dyes Pigm 174:108100

15. Albano G, Colli T, Biver T, Aronica LA, Pucci A (2020) Dyes Pigm 178:108368

16. McLaughlin EC, Doyle MP (2008) J Org Chem 73:4317-4319

17. Ajjou AN, Ferguson G (2006) Tetrahedron Lett 47:3719-3722

18. Ryu JY, Heo S, Park P, Nam W, Kim J (2004) Inorg Chem Commun 7:534-537

19. Normant JF (1972) Synthesis 1972:63-80

20. Shen Q, Huang W, Wang J, Zhou X (2008) Organometallics 27:301-303

21. Fusano A, Fukuyama T, Nishitani S, Inouye T, Ryu I (2010) Org Lett 12:2410-2413

22. Jianming L, Xingao P, Wei S, Yongwei Z, Chungu X (2008) Org Lett 10:3933-3936

23. Perrone S, Bona F, Troisi L (2011) Tetrahedron 67:7386-7391

24. Cox RJ, Ritson DJ, Dane TA, Berge J, Charmant JPH, Kantacha A (2005) Chem Commun 8:1037-1039

25. Kumar B, Maity J, Kumar A, Khatri V, Shankar B, Prasad AK (2018) Chem Het Comp 54(3):362-368

26. Breuer N, Müller TJJ (2018) Synthesis 50:2741-2752

27. Sun W, Wang Y, Wu X, Yao X (2013) Green Chem 15:2356

28. Bhosale MA, Sasaki T, Bhanange BM (2014) Catal Sci Technol $4: 4274$

29. Wang K, Yang L, Zhao W, Cao L, Sun Z, Zhang F (2017) Green Chem 19:1949

30. Loganathan RK, Ramachandra SN (2017) Shekharappa, Sureshbabu V.V. ChemistrySelect 2:8059-8062

31. Sharma RK, Yadav M, Gaur R, Gupta R, Adholeya A, Gawande MB (2016) ChemPlusChem 81:1312-1319

32. Nasrollahzadeh M, Atarod M, Alizadeh M, Hatamifard A, Sajadi SM (2017) Curr Org Chem 21(8):708-749

33. Nasrollahzadeh M, Issaabadi Z, Tohidi MM, Sajadi MM (2018) Chem Rec 18:165-229

34. Nasrollahzadeh M, Motahharifar N, Ghorbannezhad F, Baran BT, Varma RS (2019) Mol Catal 480:110645-110675

35. Keivanloo A, Bakherad M, Bahramian B, Baratnia S (2011) Tetrahedron Lett 52:1489-1502

36. Bakherad M, Keivanloo A, Bahramian B, Jajarmi S (2011) Synlett 3:0311-0314

37. Reddy KR, Suresh M, Kantam ML, Bhargava SK, Srinivasu P (2014) Ind Eng Chem Res 53:18630-18636

38. Keivanloo A, Bakherad M, Bahramian B, Rahhmani M, Taheri SA (2011) Synthesis 2:0325-0329

39. Cwik A, Hell Z, Figueras F (2006) Adv Synth Catal 348:523-530

40. Cwik A, Hell Z, Figueras F (2006) Tetrahedron Lett 47:3023-3026

41. Cwik A, Hell Z, Figueras F (2005) Org Biomol Chem 3:4307-4309

42. Fodor A, Hell Z, Pirault-Roy L (2014) Appl Catal 484:38-50

43. Fodor A, Hell Z, Pirault-Roy L (2016) Catal Lett 146:596-608

44. Periasamy M, Karunakar GV, Bharathi P (2006) J Chem Res 2006:566-568

45. Chen L, Li C-J (2004) Org Lett 6(18):3151-3153

46. Park A, Park K, Kim Y, Lee S (2011) Org Lett 13(5):944-947

47. Wu XF, Neumann H, Beller M (2010) Chem Eur J 25:12104-12107

48. Renault J, Qian Z, Uriac P, Gouault N (2011) Tetrahedron Lett 52(19):2476-2479

49. Blay G, Cardona L, Fernández I, Pedro JR (2007) Synthesis 21:3329-3332

50. Zhao T, Xu B (2010) Org Lett 12(2):212-215 
51. Fodor A, Kiss Á, Debreczeni N, Gresits I, Hell Z (2010) Org Biomol chem 8:4575-4581

52. Juhász K, Hell Z (2018) Tetrahedron Lett 59:3136-3138

53. Magyar Á, Hell Z (2016) Catal Lett 146:1153-1162

54. Magyar Á, Hell Z (2017) Per Poly Chem Eng 61(4):278-282
55. Magyar Á, Hell Z (2019) Synlett 30:89-93

56. Németh J, Debreczei N, Gresits I, Bálint M, Hell Z (2015) Catal Lett 145:1113-1119

Publisher's Note Springer Nature remains neutral with regard to jurisdictional claims in published maps and institutional affiliations. 